\title{
BILATERALNA WSPÓŁPRACA GMIN NA PRZYKŁADZIE BIAŁEGOSTOKU I GRODNA ${ }^{401}$
}

Polskie samorządy gminne prowadzą prężną współpracę międzynarodową o charakterze dwustronnym. Przykładem jest liczba zawartych umów z sąsiednimi jednostkami oraz z innymi podmiotami. Aktywność ta w głównej mierze jest związana z możliwością korzystania ze środków pomocowych Unii Europejskiej. Celem kooperacji jest podejmowanie przedsięwzięć obustronnie korzystnych w obszarze kultury, edukacji, turystyki i sportu, gospodarki, ochrony środowiska oraz wymiana doświadczeń i wiedzy. Inicjatywy są realizowane poprzez misje i targi gospodarcze, wyjazdy sportowców, wymiany młodzieży, wspólne imprezy kulturalne $\mathrm{i}$ integracyjne.

Samorządy chętnie przystępują do różnego rodzaju organizacji o charakterze lokalnym, regionalnym w celu wymiany doświadczeń, nawiązywania kontaktów i zasygnalizowania swej obecności na arenie międzynarodowej. ${ }^{402}$ Bilateralna współpraca samorządów lokalnych po obu stronach granicy często stanowi formę dyplomacji oddolnej, ponieważ jest realizowana przez gminy (najniższa jednostka podziału terytorialnego kraju). Aktywność władz lokalnych z różnych państw umożliwia samoorganizację podmiotów, dzięki czemu wzmacniają one coraz bardziej swą pozycję względem władz państwowych. Podkreślić należy, że tak prowadzona kooperacja sprawia, że relacje międzynarodowe odbywają się na szczeblu lokalnym. ${ }^{403}$ Efektem takiej współpracy jest obopólne poznanie się oraz zbliżenie się społeczeństw lokalnych obu krajów. ${ }^{404}$

\footnotetext{
* $\quad$ Pracownik Biura Funduszy Europejskich Urzędu Miejskiego w Białymstoku.

401 Autor pierwotnie poruszył tematykę współpracy samorządów Białegostoku i Grodna w miesięczniku „Orzecznictwo Sądów w Sprawach Gospodarczych” 2012, nr 3, s. 94-107. Ponadto zagadnienia poruszane w artykule posłużą do szerszej analizy w rozprawie doktorskiej.

402 E. Szadkowska, Bilateralna współpraca samorządowa jako forma współpracy transgranicznej, [w:] M. Perkowski (red.), Współpraca transgraniczna. Aspekty prawno-ekonomiczne, Białystok 2010, s.102.

403 H. Zięba-Załucka, Współpraca międzynarodowa samorządów, „Samorząd Terytorialny” 2008, nr 1-2, s. 63.

404 A. Skorupska, Współpraca międzynarodowa samorządu gminnego na podstawie badań, [w:] Współpraca międzynarodowa samorządu gminnego, pod red. A. Skorupskiej, Warszawa 2005, s. 7.
} 


\section{Bilateralna współpraca gmin - podstawy prawne}

Reformy ustrojowe, jakie miały miejsce w Polsce po 1989 roku, a zwłaszcza przywrócenie samorządu terytorialnego, umożliwiły samorządom krajowym nawiązywanie kooperacji z jednostkami innych krajów. Efektem tej transformacji było unormowanie zasad uczestnictwa jednostek samorządu terytorialnego w relacjach międzynarodowych. ${ }^{405}$

Do podstawowych aktów prawnych bilateralnej współpracy gmin zalicza się:

- regulacje prawnomiędzynarodowe:406

- Europejską Kartę Samorządu Lokalnego podpisaną w Strasburgu 15 października $1985 \mathrm{r}^{407}$ : zgodnie z art. 10 ust. 2 i 3 ,przewiduje się prawo społeczności lokalnych do współpracy ze społecznościami innych państw na warunkach przewidzianych prawem oraz do przystąpienia do międzynarodowego stowarzyszenia społeczności lokalnych";

- umowy dwustronne między Polską a Białorusią:

- Deklarację o dobrym sąsiedztwie, wzajemnym zrozumieniu i współpracy między Rzecząpospolitą Polską i Republiką Białoruś, podpisaną 10 października 1991 r.;

- Porozumienie między Rządem Rzeczypospolitej Polskiej a Rządem Republiki Białoruś o głównych zasadach współpracy transgranicznej, podpisane 24 kwietnia 1992 r.;

- Traktat między Rzecząpospolitą Polską i Republiką Białoruś o dobrym sąsiedztwie i przyjaznej współpracy, podpisany 23 czerwca 1992 r.; 408

- polskie akty prawne; 409

- Konstytucję Rzeczypospolitej Polskiej z 2 kwietnia 1997 r. ${ }^{410}$ : jej art. 172 stanowi, że: ,jednostka samorządu terytorialnego ma prawo przystępowania do międzynarodowych zrzeszeń społeczności lokalnych i regionalnych oraz współpracy ze społecznościami lokalnymi i regionalnymi innych państw";

Ibidem, s. 12-13.

Prawnomiędzynarodowe źródła współpracy regionalnej Polski, w opracowaniu A. Przyborowskiej-Klimczak, W.S. Staszewskiego, S. Wrzoska, Białystok 2000, s. 8.

Europejska Karta Samorządu Lokalnego sporządzona w Strasburgu 15 października 1985 r., Dz.U. z 1994 r. nr 124, poz. 607.

Traktat między Rzecząpospolitą Polską i Republiką Białoruś o dobrym sąsiedztwie i przyjaznej współpracy, podpisany 23 czerwca 1992 r., Dz.U. z 1993 r. Nr 118, poz. 527.

M. Juchnicka, E. Skibicka-Sokołowska, Podstawy prawne i uwarunkowania współpracy transgranicznej, [w:] W. Bieńkowski, J. Grabowiecki, H. Wnorowski (red.), Współpraca transgraniczna Polski z krajami bałtyckimi, Białorusią i Rosją - Obwód Kaliningradzki uwarunkowania i perspektywy rozwoju, Wydawnictwo Uniwersytetu w Białymstoku, Białystok 2002, s. 115.

Konstytucja Rzeczypospolitej Polskiej z dnia 2 kwietnia 1997 r., Dz.U. z 1997 r. Nr 78, poz. 483. 
- Ustawa o samorządzie gminnym z dnia 8 marca $1990 \mathrm{r}^{4}{ }^{41}$ : wg art. 18 ust. 2 pkt. 12a do wyłącznej właściwości rady gminy należy „podejmowanie uchwał w sprawach współpracy ze społecznościami lokalnymi i regionalnymi innych państw oraz przystępowania do międzynarodowych zrzeszeń społeczności lokalnych i regionalnych"; ${ }^{412}$

- Ustawa o zasadach przystępowania jednostek samorządu terytorialnego do międzynarodowych zrzeszeń społeczności lokalnych i regionalnych z dnia 15 września 2000 r.. ${ }^{413}$,jednostki samorządu terytorialnego mogą przystępować do zrzeszeń i uczestniczyć w nich w granicach swoich zadań oraz kompetencji, działając zgodnie z polskim prawem wewnętrznym, polityką zagraniczną państwa i jego międzynarodowymi zobowiązaniami". ${ }^{414}$

Z problematyką bilateralnej współpracy gmin związana jest międzynarodowa współpraca transgraniczna i regionalna. Zgodnie z Europejską konwencją ramową o współpracy transgranicznej między wspólnotami i władzami terytorialnymi (dokument Rady Europy podpisany 21 maja 1980 roku w Madrycie) współpraca transgraniczna to każde wspólnie realizowane przedsięwzięcie, którego celem jest umocnienie i rozwój sąsiedzkich relacji między społecznościami i władzami terytorialnymi co najmniej dwóch stron oraz podpisanie porozumień i przyjęcie uzgodnień niezbędnych do realizacji takich działan. ${ }^{415}$ Umożliwia ona wymianę doświadczeń regionów z różnych krajów, co warunkuje podniesienie jakości działania samorządów, rozwój turystyki, sportu, kultury oraz realizację wielu inwestycji infrastrukturalnych. Wyjątkowym typem kontaktów zagranicznych są miasta partnerskie. Geneza związków bliźniaczych gmin związana jest z zakończeniem II wojny światowej. Kooperacja miast i gmin miała w przyszłości zapobiec konfliktom zbrojnym w Europie, pomóc w zbliżeniu się społeczności z różnych państw oraz przezwyciężyć wzajemną wrogość między zwaśnionymi narodami.

\section{Bilateralna współpraca gmin - założenia}

Współcześnie duże znaczenie w budowaniu i rozwijaniu partnerskich stosunków między regionami odgrywa bilateralna współpraca przygranicznych miast. Zawarte porozumienia między współpracującymi jednostkami samorządu terytorial-

\footnotetext{
411 Ustawa z dnia 8 marca 1990 r. o samorządzie gminnym, Dz.U. z 1990 r. Nr 142, poz. 1591 z późn. zm.

412 Ibidem.

413 Ustawa z dnia 15 września 2000 r. o zasadach przystępowania jednostek samorządu terytorialnego do międzynarodowych zrzeszeń społeczności lokalnych i regionalnych, Dz.U. z 2000 r. Nr 91, poz. 1009 z późn. zm.

414 A. Skorupska, Współpraca międzynarodowa samorządu gminnego na podstawie badań, [w:] Współpraca międzynarodowa samorządu gminnego, pod red. A. Skorupskiej, Warszawa 2005, s.13.

415 A. Żelazo, Pojęcie współpracy transgranicznej samorządu terytorialnego, „Biuletyn Polskiego Instytutu Spraw Międzynarodowych" 2004, nr 24, s 1.
} 
nego miast leżących po dwóch stronach tej samej granicy mają na celu umocnienie i rozwój przyjaznych stosunków pomiędzy lokalnymi społecznościami. Miasta partnerskie w ramach podpisanych porozumień i umów zobowiązują się kreować i popierać współpracę transgraniczną w wielu dziedzinach (na przykład: gospodarka, edukacja, turystyka, sport). Fundamentalnym celem kooperacji jest wymiana doświadczeń, współpraca przedsiębiorstw, wspólne działania dotyczące opracowania projektów unijnych, wymiana sportowa, kulturalna.

Postępująca integracja Europy doprowadziła do rozwoju współpracy transgranicznej.

Organizacyjnymi formami współpracy transgranicznej władz lokalnych są euroregiony i związki bliźniacze (partnerskie). Związki bliźniacze gmin są instrumentem budowania i realizowania polityki zagranicznej rządu. Ich cechą charakterystyczną jest bezpośrednie angażowanie się mieszkańców gmin, organizacji i stowarzyszeń lokalnych w kooperację ze społecznościami gmin zagranicznych. Dodać należy, że partnerstwa gmin są formą współpracy międzynarodowej na szczeblu lokalnym, wzajemną wymianą doświadczeń i współpracą w różnych obszarach życia społecznego. ${ }^{416}$

Ruch miast partnerskich jest współcześnie bardzo popularną formą współpracy między narodami. Większość gmin europejskich państw posiada partnera poza granicami swojego kraju (najczęściej miasta Niemiec i Francji). Ponad 650 polskich miast ma partnera z Niemiec i Francji. O podjęciu współpracy między miastami decyduje bliskość geograficzna, bliskość interesów, tradycja, historia. Współpraca miast bliźniaczych może przybrać formę tradycyjną i nowoczesną. W tradycyjnej formie ważne jest utrzymywanie wzajemnych kontaktów. Miasta współpracują w dziedzinie sportu, kultury, wymiany uczniów. Najaktywniejszymi uczestnikami wzajemnych spotkań są osoby młode. Z kolei nowoczesna współpraca miast bliźniaczych koncentruje się przede wszystkim na rozwijaniu współpracy gospodarczej (np. stwarzanie preferencji podatkowych w celu zachęcenia partnera do inwestowania na rynku lokalnym miasta współpracującego czy też wymiana doświadczeń w zarządzaniu lokalnym). W czasie obustronnych wizyt partnerzy obserwują rozwiązania architektoniczne i komunalne i przenoszą je na własne terytorium. W rezultacie kooperacji do miasta partnerskiego zapraszani są urzędnicy drugiego miasta w celu odbycia stażu, przeszkolenia. Reasumując, stwierdzić należy, że między tradycyjną i nowoczesną współpracą miast bliźniaczych jest w gruncie rzeczy bardzo pozorna granica. Nowi partnerzy swoją współpracę rozpoczynają bowiem od tradycyjnych spotkań, od wymiany młodzieży, a realizują poprzez przedsięwzięcia gospodarcze. ${ }^{417}$

416 A. Żelazo, Samorząd gminny w stosunkach międzynarodowych, „Polski Przegląd Dyplomatyczny” 2001, nr 2, s. 1.

417 E. Kalitta, Rola miast partnerskich w budowaniu przyjaźni między narodami. Przykład Chojnic, „Samorząd Terytorialny" 2008, nr 12, s. 27. 
Zinstytucjonalizowaną formą współpracy transgranicznej są euroregiony (obecnie także Europejskie Ugrupowanie Współpracy Terytorialnej). Funkcjonują one w oparciu o porozumienia między władzami szczebla lokalnego oraz regionalnego, a w niektórych sytuacjach także z udziałem organizacji gospodarczych i społecznych. Celem kooperacji europejskiej jest podejmowanie przedsięwzięć obustronnie korzystnych w obszarze gospodarki, nauki, oświaty, kultury oraz poszerzanie i optymalizacja kontaktów mieszkańców i przedsiębiorstw. ${ }^{418}$

\section{Ogólna charakterystyka podmiotów bilateralnej współpracy - Białegostoku (Rzeczpospolita Polska) i Grodna (Republika Białoruś)}

Przykładem współpracy transgranicznej w ramach związków bliźniaczych (partnerskich) jest kooperacja miasta Białystok (Rzeczpospolita Polska) i miasta Grodno (Republika Białoruś). Białystok to stolica województwa podlaskiego i największa aglomeracja północno-wschodniej Polski. Obszar miasta to $102,12 \mathrm{~km}^{2}$ (0,5\% powierzchni województwa podlaskiego). Liczba mieszkańców Białegostoku wynosi 295,2 tys. (dane z 2010 roku), ${ }^{419}$ z kolei gęstość zaludnienia wynosi 2880 osób na $\mathrm{km}^{2}$ (drugie miasto o największej gęstości zaludnienia w Polsce po Warszawie). Dodać należy, że miasto Białystok razem z jednostkami samorządu terytorialnymi powiatu białostockiego, sokólskiego oraz z powiatem białostockim i sokólskim tworzy Białostocki Obszar Metropolitarny. Do najważniejszych miast partnerskich Białegostoku należy zaliczyć: Eindhoven (Holandia, data podpisania porozumienia: 29.09.1992 r.), Kowno (Litwa, data podpisania listu intencyjnego: 12.01.1994 r.), Hrabstwo Milwaukee (Stany Zjednoczone, data podpisania porozumienia - memorandum: 17.03.1995 r.), Dystrykt Dijon (Francja, data podpisania oświadczenia o współpracy: 30.03.1996 r.), Grodno (Republika Białoruś, data podpisania porozumienia: 16.06.2000 r.), Kaliningrad (Federacja Rosyjska, data podpisania porozumienia: 22.06.2002 r.), Psków (Federacja Rosyjska, data podpisania porozumienia: 25.07.2002 r.). ${ }^{420}$

Białystok ściśle współpracuje z białoruskim Grodnem. Grodno jest miastem obwodowym na zachodzie Białorusi w pobliżu polskiej granicy. Cechą aglomeracji jest jej wielonarodowość. Od wielu lat żyją tam przedstawiciele ponad 6 narodowości i różnych wyznań. Grodno położone jest nad rzeką Niemen - trzecią pod względem długości rzeką Republiki Białoruś. Miasto liczy 330,3 tys. mieszkańców. Jego

\footnotetext{
418 A. Żelazo, Współpraca międzynarodowa gmin przygranicznych, „Biuletyn Polskiego Instytutu Spraw Międzynarodowych" 2002, nr 59, s. 1.

419 Tekst pochodzi ze strony: http://www.stat.gov.pl/cps/rde/xbcr/bialystok/ASSETS_10m01_02.pdf, stan na dzień: 03.11.2012 r.

420 Tekst pochodzi ze strony: http://www.bialystok.pl/269-wspolpraca-zagraniczna/default.aspx, stan na dzień: 04.11.2012 r.
} 
powierzchnia ogólna wynosi $142 \mathrm{~km}^{2}$ (dane za 2009 rok). ${ }^{421}$ Zestawienie porównawcze podstawowych informacji o Białymstoku i Grodnie przedstawia Tabela 1.

Tabela 1. Podstawowe informacje o Białymstoku i Grodnie

\begin{tabular}{|l|c|c|}
\hline Wyszczególnienie & Grodno & Białystok \\
\hline Powierzchnia ogólna w km² & 142 & 102 \\
\hline Ludność w tys. & 330,3 & 294,7 \\
\hline $\begin{array}{l}\text { Ludność na 1 km² powierzchni ogólnej } \\
\text { miasta }\end{array}$ & 2326 & 2886 \\
\hline Mediana wieku (wiek środkowy) & 34,6 & 37,4 \\
\hline Przyrost naturalny na 1000 ludności & 4,8 & 2,7 \\
\hline Bezrobotni zarejestrowani w tys. & 2,3 & 14,1 \\
\hline Szkoły wyższe & 3 & 11 \\
\hline Studenci szkół wyższych w tys. & 30,1 & 47,2 \\
\hline Teatry & 2 & 5 \\
\hline Turystyczne obiekty zbiorowego \\
zakwaterowania
\end{tabular}

Źródto: Grodno i Białystok w 2009 roku, Urząd Statystyczny w Białymstoku, Biatystok 2011, s. 9-31.

\section{Dokumenty określające ramy bilateralnej współpracy pomiędzy Białymstokiem a Grodnem}

Pierwsze porozumienie o współpracy Białegostoku i Grodna zostało podpisane dnia 16 czerwca 2000 roku. Określona w ten sposób współpraca pomiędzy partnerskimi miastami skupiała się przede wszystkim na obszarach dotyczących gospodarki, edukacji i kultury. Porozumienie obowiązywało przez 3 lata. Zgodnie $\mathrm{z}$ umową termin uległ automatycznemu przedłużeniu na następne 3 lata. ${ }^{422}$ Zgodnie

421 Grodno i Białystok w 2009 roku, Wydawnictwo: Urząd Statystyczny w Białymstoku, Białystok 2011, s. 9.

422 Porozumienie o współpracy pomiędzy Miastem Grodno (Białoruś) i Miastem Białystok (Polska) na lata 20002003, pkt. 8, zasoby Urzędu Miejskiego w Białymstoku. 
z zapisami porozumienia przyjęto na lata 2000-2003 następujący program współpracy pomiędzy miastem Grodno i miastem Białystok ${ }^{423}$ :

- w sferze gospodarczej budowane będą warunki do współpracy pomiędzy właściwymi organizacjami w Grodnie i Białymstoku; w ramach tych działań strony zobowiązują się do inspirowania współpracy Izb Przemysłowo-Handlowych w Grodnie i Białymstoku; pomocy w odnajdywaniu partnerów do kooperacji; zachęcania przedsiębiorców do brania udziału w wystawach w Grodnie i Białymstoku;

- w dziedzinie wymiany informacji partnerskie miasta będą inicjowały współpracę pomiędzy mediami w obydwu miastach (np. wymiana materiałów wydawniczych, programów radiowych i telewizyjnych); wzajemne wyjazdy dziennikarzy do Grodna i Białegostoku; kooperację pomiędzy Rzecznikami Prasowymi Mera Grodna i Prezydenta Miasta Białegostoku;

- w obszarze kultury, sztuki, oświaty, nauki, sportu, turystyki obydwa miasta będą inspirowały i popierały wymianę i współpracę pomiędzy zainteresowanymi podmiotami w Grodnie i Białymstoku (uczelniami i szkołami; podmiotami odpowiedzialnymi za kulturę, sztukę i turystykę);

- w sferze wymiany doświadczeń pomiędzy organami samorządów, miasta będą prowadziły wymianę informacji w następujących obszarach: działania organów samorządowych, ochrony przyrody, gospodarki komunalnej, transportu zbiorowego, opieki socjalnej, sportu, kultury i sztuki.

W ramach porozumienia o współpracy pomiędzy Białymstokiem a Grodnem realizowane miały być projekty warunkujące promowanie obustronnych stosunków i stabilizacji socjalnej obydwu miast (np. projekty finansowane przez instytucje europejskie). Dodać należy, że szczególne traktowanie zarezerwowano na rzecz projektów w dziedzinie rozwoju kultury mniejszości narodowych. ${ }^{424}$

Kontynuacją kooperacji Białegostoku i Grodna było podpisanie Umowy o współpracy pomiędzy Miastem Białystok a Miastem Grodno z dnia 16 grudnia 2009 r. Dokument został zawarty na podstawie Uchwały Nr XLV/557/09 Rady Miejskiej Białegostoku z dnia 7 września 2009 r. w sprawie podjęcia współpracy z miastem Grodno (Republika Białoruś). Obydwie strony określiły podstawowe kierunki i formy współpracy realizowanej na zasadach partnerstwa, równości, zaufania i obustronnych korzyści w następujących dziedzinach:

- gospodarka;

- wymiana doświadczeń z dziedziny realizacji zadań publicznych;

- kultura, sztuka, oświata, nauka i turystyka; 
- sport;

- ochrona zdrowia. ${ }^{425}$

W sferze gospodarczej partnerskie miasta postanowiły inicjować i wspierać rozwój współpracy pomiędzy odpowiednimi organizacjami i podmiotami (np. budować warunki do optymalnej współpracy Izb Przemysłowo-Handlowych oraz innych organizacji i podmiotów gospodarczych z Białegostoku i Grodna). W dziedzinie informacji podejmowane mają być działania polegające na wspieraniu współpracy środków masowego przekazu (np. wymiana materiałów informacyjnych, wspólne przygotowanie programów radiowych i telewizyjnych).

W sferze sportu współpracujące miasta zamierzają inicjować działania w zakresie wymiany doświadczeń oraz wspierać obustronne kontakty między klubami, stowarzyszeniami, instytucjami sportowymi. Priorytetowo będzie traktowana wspólna organizacja wydarzeń sportowych (np. mecze sportowe). Dodać należy, że obydwa miasta będą prowadzić wzajemną wymianę doświadczeń w kwestii działania administracji publicznej (m.in. funkcjonowanie samorządu terytorialnego). ${ }^{426}$

\section{Praktyczne efekty bilateralnej współpracy Białegostoku i Grodna}

W ramach bilateralnej współpracy Białegostoku z Grodnem podjęto szereg inicjatyw w dziedzinie kultury, sportu, gospodarki oraz edukacji. Do powyższych przedsięwzięć należy zaliczyć zorganizowanie misji gospodarczej do Grodna oraz wyjazdy sportowców do Grodna w 2009 roku. Dla przykładu można podać, że miasto Białystok, udzielając dotacji na realizację zadań z dziedziny sportu dla organizacji sportowych, na podstawie Umowy o współpracy z dnia 16 grudnia 2009 r. zawartej pomiędzy Białymstokiem a Grodnem, przyjęło następujące propozycje współpracy w 2011 roku w obszarze wspierania wzajemnych kontaktów między klubami, stowarzyszeniami i instytucjami sportowymi ${ }^{427}$ :

- Uczniowski Klub Sportowy „Hubal” zaproponował udział zawodników z Grodna w Międzynarodowym Turnieju Badmintona (2122.05.2011 r.); w Międzynarodowym Turnieju Badmintona „Turniej Asów” (28-29.05.2011 r.);

425 Uchwała Nr XLV/557/09 Rady Miejskiej Białegostoku z dnia 7 września 2009 r. w sprawie podjęcia współpracy z miastem Grodno (Republika Białoruś), §1. Tekst pochodzi ze strony: www.bip.bialystok.pl/290szczegolyuchwaly/lang/pIPL/id/lfdBc1D5u3Hqppm9tzNDw2/back/289/default.aspx.

426 Umowa o współpracy pomiędzy Miastem Białystok a Miastem Grodno z dnia 16 grudnia 2009 r. art. 1-6, z zasobów własnych Urzędu Miejskiego w Białymstoku.

427 Opracowanie własne na podstawie materiałów wewnętrznych Biura Sportu i Rekreacji Urzędu Miejskiego w Białymstoku. 
- Klub Sportowy „Cristal” wspólnie z Podlaskim Okręgowym Związkiem Bokserskim utrzymuje stałe kontakty sportowe w boksie z Grodzieńską Państwową Szkołą Rezerw Olimpijskich; klub zaproponował wspólny udział zawodników Grodna i Białegostoku w kilku imprezach (np. Turniej na dni miasta Białegostoku - czerwiec 2011 r.; Międzynarodowy Turniej Bokserski im. R. Kułakowskiego - wrzesień 2011 r.);

- Białostocki Klub Sportowy „Hetman” zaprosił zawodników z Grodna do rozegrania wspólnych meczów i konsultacji szkoleniowych (zorganizowania międzynarodowego meczu bokserskiego pomiędzy zawodnikami miasta Białegostoku i Grodna - październik - listopad 2011 r.);

- Podlaski Klub Koszykówki „Żubry” zaproponował udział drużyny z Grodna w Międzynarodowym Turnieju Koszykówki o Puchar Prezesa Żubrów (grudzień 2011 r.); w Turnieju Streetballowym z okazji Dnia Dziecka (maj 2011 r.);

- Miejski Ośrodek Szkolenia Piłkarskiego „Jagiellona” Białystok zadeklarował kontynuację współpracy z Klubem Biełkard Grodno (w poprzednich latach drużyny rozgrywały towarzyskie mecze piłkarskie);

- Uczniowski Klub Sportowy „Kaliber” stale współpracuje z Wyższą Szkołą Mistrzostwa Sportowego z Grodna i zaproponował udział zawodników z Grodna w zawodach w strzelectwie sportowym (np. „Polish Open Kaliber 2011" 1-4.12.2011 r.).

W dziedzinie ochrony zdrowia instytucje ochrony zdrowia z Białegostoku współpracują z placówkami z Grodna (np. Białostockie Centrum Onkologii, Wojewódzki Szpital Zespolony w Białymstoku oraz Specjalistyczny Zakładu Opieki Zdrowotnej Gruźlicy i Chorób Płuc współpracują z Obwodowym Grodzieńskim Szpitalem Klinicznym). W obszarze gospodarczym Podlaska Fundacja Rozwoju Regionalnego podjęła współpracę w ramach projektu Enterprise Europe Network z partnerami białoruskimi (np. poszukiwanie partnerów handlowych, technologicznych; organizacja międzynarodowych spotkań kooperacyjnych i zagranicznych misji gospodarczych; organizacja bezpłatnych seminariów informacyjnych na temat zakładania i prowadzenia działalności gospodarczej na Białorusi). ${ }^{428}$ Dodać należy, że 29 czerwca 2011 r. miało miejsce spotkanie z piętnastoma białoruskimi przedstawicielami Grodzieńskiego Klubu Przedsiębiorców oraz Grodzieńskiej Wolnej Strefy Ekonomicznej. W spotkaniu poruszane były kwestie dotyczące, np. warunków do inwestowania w Suwalskiej Specjalnej Strefie Ekonomicznej, funkcjonowania Białostockiego Parku Naukowo-Technologicznego, a także planów inwestycyjnych miasta na najbliższy okres. Podkreślić należy, że w dniach 28-30 września

428 Opracowanie własne na podstawie materiałów wewnętrznych Departamentu Współpracy z Zagranicą i Promocji Urzędu Marszałkowskiego Województwa Podlaskiego w Białymstoku. 
2011 roku odbyło się w Grodnie III Międzynarodowe Forum Inwestycyjne „Grodno - miasto na skrzyżowaniu granic”, w którym uczestniczyły władze Białegostoku. ${ }^{429}$

W sferze kultury Wojewódzki Ośrodek Animacji Kultury w Białymstoku zaprosił do udziału w „Podlaskiej Oktawie Kultur” zespoły z Grodna (2010 r.). W dziedzinie nauki Uniwersytet w Białymstoku bezpośrednio współpracuje z uczelniami z Białorusi m.in. w obszarze prowadzenia badań naukowych, w wymianie wyników badań, w wymianie pracowników naukowych i studentów, uczestnictwo w konferencjach, wspólne przygotowanie publikacji naukowych. Dla przykładu można podać, że w 2010 r. na Uniwersytet w Białymstoku przyjechało 6 pracowników naukowych z Państwowego Uniwersytetu im. Janki Kupały w Grodnie. ${ }^{430}$

\section{Podsumowanie}

Reasumując, stwierdzić należy, że Białystok od wielu lat pozostaje w bliskich relacjach z Grodnem. Pierwsze porozumienie dotyczące współpracy zostało podpisane 16 czerwca 2000 roku. Sformalizowana współpraca obu miast skupiała się przede wszystkim na dziedzinach dotyczących gospodarki, edukacji oraz kultury. Kontynuacją współpracy obu miast było podpisanie Umowy o współpracy 16 grudnia 2009 roku. Przedstawiciele Białegostoku uczestniczą w spotkaniach kulturalnych, gospodarczych (np. Forum Inwestycyjne „Grodno-Miasto na skrzyżowaniu granic”). Ważnym obszarem współpracy jest sport na poziomie klubów (np. boks, strzelectwo sportowe, piłka nożna, koszykówka). Kontakty te opierają się na uczestnictwie klubów z Grodna i Białegostoku w zawodach sportowych. Dodać należy, że współpraca partnerska Białegostoku i Grodna w dziedzinie gospodarki, wymiany doświadczeń z zakresu realizacji zadań publicznych, kultury, sztuki, oświaty, nauki, turystyki, sportu i ochrony zdrowia wpływa na poprawę obustronnych stosunków i tworzy grunt pod trwałe wspólne przedsięwzięcia w (ewentualnie lepszej politycznie) przyszłości. Oczywiście że, jak każda forma podejmowanej współpracy międzynarodowej, kooperacja białostocko-grodzieńska musi bazować na partnerstwie i obopólnych korzyściach, a jej rezultaty zależeć będą od zaangażowania, determinacji i kompetencji partnerów.

429 Opracowanie własne na podstawie materiałów wewnętrznych Biura Rady Miejskiej Urzędu Miejskiego w Białymstoku.

430 Opracowanie własne na podstawie materiałów wewnętrznych Departamentu Współpracy z Zagranicą i Promocji Urzędu Marszałkowskiego Województwa Podlaskiego w Białymstoku. 


\section{BILATERAL COOPERATION OF MUNICIPALITIES. THE CASE OF BIALYSTOK AND GRODNO}

The conduct of international cooperation on a bilateral basis is a fundamental feature of Polish local governments. It is reflected in the number of agreements with neighboring and other entities. An example of bilateral cooperation of municipalities is cooperation of the city of Bialystok (Republic of Poland) and the city of Grodno (Republic of Belarus). For many years Bialystok has maintained close contacts with Grodno. The first agreement on cooperation was signed on 16 June 2000. The cooperation between the two cities focused mainly on the areas of economy, education and culture. The next stage of cooperation of the cities came with the Agreement on Cooperation of 16 December 2009. Representatives of Bialystok participate in cultural, economic meetings (e.g. the Investment Forum ,, Grodno - a Town at the Junction of Borders"). One of the areas of cooperation between Bialystok and Grodno is sport at club level (e.g. boxing, shooting, football, basketball). These contacts are based on the participation of sports clubs from Grodno and Bialystok. Other important areas of cooperation between the partner cities are: economy, exchange of experiences in the field of public tasks execution, culture, art, education, science, tourism, and health care. The implementation of bilateral projects in these areas improves bilateral relations and builds friendship between the cities. It should be emphasized that undertaking any form of international cooperation must be based on partnership and mutual benefits, and its effectiveness will depend on commitment, determination and competence of the partners.

Keywords:

Twinning towns, transboundary cooperation, Bialystok, Grodno 